\section{Performance of waste glass powder (WGP) supplementary cementitious material (SCM) - Drying shrinkage and early age shrinkage cracking}

PatRICIJA KARA - Scientific researcher, RTU, Riga, Latvia - patricija.kara@rtu.lv

ADORJÁN BOROSNYÓI - Associate Professor, BME, Budapest, Hungary • borosnyoi.adorjan@epito.bme.hu OLIVÉR FENYVESI - Senior Lecturer, BME, Budapest, Hungary • fenyvesioliver@yahoo.com

Érkezett: 2014. 02. 26. - Received: 26. 02. 2014. • http://dx.doi.org/10.14382/epitoanyag-jsbcm.2014.4

\begin{abstract}
EU laws have been the most effective driving force of Latvian and Hungarian environmental legislation in order to improve recycling of packaging waste. In Latvia and Hungary the waste diversion strategies have focused on establishing treatment capacity and setting up schemes for separate collection, which largely cover packaging waste. Despite all improvements done in this area, still large amount of glass wastes is dumped into landfills and alternative solution for this waste glass utilization could be the application in concrete as a supplementary cementitious material (SCM). Laboratory tests were carried out on cement paste specimens, in which waste glass powder (WGP) addition was used as a SCM. Cement was substituted with WPG at levels of $20 \%$ or $30 \%$ per mass. It was demonstrated that the WGP addition is applicable in view of drying shrinkage with total deformation up to $2.5 \%$ in the period of 592 days. The WGP addition contributes to a slowdown in the rate of hydration of the cement paste, so the early age shrinkage cracking tendency becomes more favourable, which can be seen in the longer cracking time result during the ring tests.

Keywords: recycling, waste glass, supplementary cementitious material, drying shrinkage, early age shrinkage cracking
\end{abstract}

\section{Introduction}

Both industrial and municipal wastes are key environmental, social and economic issues and a growing problem, since the amount of waste generated in European continues is rising each year. Waste management has become increasingly sophisticated, since separate collection and recycling facilities have become commonplace and landfill and incineration standards have become more rigorous. However, rising global consumption patterns put increasing pressure on ecosystems and waste infrastructure [1]. Greenhouse gas emission is also becoming more and more relevant in waste management planning. In countries that have very low landfill rates, waste recycling and energy recovery can help avoiding greenhouse gas emissions from the production of material or energy [2]. As an example, the use of 1 ton of cullet (crushed recycled glass), in comparison with 1 ton of natural raw material (sand), releases $500 \mathrm{~kg}$ less of carbon dioxide (quarrying, transport and fusion included).

Since Hungary and Latvia have joined the European Union (EU) in 2004, EU laws have been the most effective driving force of Hungarian and Latvian environmental legislation in order to improve recycling of packaging waste. In Hungary and Latvia the waste diversion strategies have focused on establishing treatment capacity and setting up schemes for separate collection, which largely cover packaging waste.

Hungarian performance in terms of municipal waste management recycling has been improving considerably over the last decade from close-to-zero ( $2 \%$ in 2001) to $21 \%$ in 2010 , while at the same time municipal waste management generation
Patricija Kara

Civil engineer (MSc), PhD candidate, Scientific researcher, Lecturer at Riga Technical University (RTU), Institute of Materials and Structures (IMS), Department of Building Materials and Products. Member of ACl Italy Chapter. RLLEM Affiliate Member, TC AAA, TC 225-SAP and TC 219-ACS Member of Latvian Materials Research Society. Member of LVS STK 30 Eurocode Sub-Committee. Main research area: concrete technology, waste glass recycling, recycling of industrial wastes and by-products in concrete, environmenta management, eco-construction materials.

Adorján Borosnyói Civil engineer (MSc), PhD, Associate Professo at BME Dept. of Construction Materials and Engineering Geology. Main fields of interest: cracking and deflection of reinforced concrete, application of non-metallic (FRP) reinforcements for concrete structures, bond in concrete, nondestructive testing of concrete, supplementary cementing materials for high performance concretes, concrete technology. Secretary of the fib Task Group 4.1 "Serviceability Models" and Chairman of the SZTE Concrete Division.

Olivér Fenyvesi Civil engineer (MSc), monument protection engineer, PhD, Senior Lecturer at BME Dept. of Construction Materials and Engineering Geology. Main fields of interest: early age shrinkage cracking of normal and lightweight concretes, application of recycled waste materials as concrete (normal and lightweight) aggregates, protection of building heritage, building diagnostic, corrosion of reinforced concrete and steel structures. Secretary of the SZTE Concrete Division, member of fib Hungarian Group.

has decreased by $13 \%$ and decoupled from economic growth over 2001-2010. If the increase rate for recycling of the last 5 years can be maintained, then the recycling rate would reach $47 \%$ in 2020 which is slightly under the $50 \%$ target set in the EU legislation for 2020 [3]. It is estimated that the municipal waste management contained around 5.9 \% glass in Hungary in 2012 [4]. 20000 tons are recycled annually by Maltha Ltd. and the rest of glass waste is exported mostly to the Czech Republic.

Approximately 50,000 tons of glass packaging waste is generated annually in Latvia. In 2013 waste sorting (mainly waste glass and plastics) has become more popular in Latvia than it was in the previous years. This is evidenced by the presence of special waste separation containers and drop-off points for wastes in Latvia. However, there is still absence of factories [5] which could recycle glass wastes and Latvian recycling infrastructure is based mostly on limited operations like: waste glass collection, sorting and export to EU by several companies dealing with preparation of glass for re-use to the neighbour countries.

\section{Durability aspects of the application of waste glass as supplementary cementitious material}

Millions of tons of glass cullet are landfilled throughout the planet every year. Over the last two decades, several studies have been carried out by researchers to solve the disposal problem of glass cullet [6]. The concrete industry is one of 
the potential users of reusing millions of tons of glass cullet per year either as aggregate or supplementary cementitious material (SCM). However, durability concerns over alkali-silica reaction (ASR) have limited the use of glass as a fine aggregate replacement in concrete [7]. Several studies have shown that glass behaves pozzolanically if ground finely enough, with a specific surface area of more than $300 \mathrm{~m}^{2} / \mathrm{kg}$ [8-13]. Towards sustainable development only a few studies were published on the investigation of drying shrinkage and early age shrinkage cracking properties of cement stone in which cement is substituted with glass waste finely ground powder. Drying shrinkage is defined as the time-dependent volume change induced by water loss in a specimen which is allowed to be dried due to exposure to an environment with certain relative humidity and temperature. The restraint of drying, autogenous or thermal shrinkage can result in the development of tensile residual stresses. Residual stresses develop over time since shrinkage occurs in response to moisture loss. If the residual stresses that develop are large enough, they may cause cracking of concrete. Crack occurrence time, crack development, crack width and free drying shrinkage strain all depend on physical and mechanical properties of cement and waste glass powder applied.

\section{Experimental studies}

Laboratory tests were carried out on cement paste specimens, in which waste glass powder (WGP) addition was used as a supplementary cementitious material (SCM) during a cooperation research between the Budapest University of Technology and Economics (BME), Department of Construction Materials and Engineering Geology and the Riga Technical University (RTU), Institute of Materials and Structures (IMS), Department of Building Materials and Products. Preliminary results on workability and compressive strength are introduced in [14].

\subsection{Materials}

Ordinary Portland cement CEM I 42.5 N was used provided by a Hungarian cement factory. Waste glass powders (WGPs) were prepared in RTU IMS laboratory directly for the present experiments, using waste glass cullet collected in Latvia. Five different WGPs were studied [14]. Fluorescent lamp tube glass waste cullet (LB) and incandescent light bulb borosilicate glass waste cullet (DRL) were received from a lamp recycling centre in Liepaja, Latvia. Container glass was obtained as bottles in green $(\mathrm{G})$, amber $(\mathrm{A})$ and flint (F) colours which were collected at a glass bottle return point in Riga, Latvia, and were manually crushed into cullet under laboratory conditions. The cullet was washed, dried and ground for 30 minutes in a laboratory planetary ball mill (Retsch PM400) with rotation speed $300 \mathrm{~min}^{-1}$. The specific surface area of the WGP was obtained by a Zwick/ Roell ToniPERM automatic Blaine apparatus (see Table 1).

$\begin{array}{cccccc}\text { DRL } & \text { LB } & \text { A } & \text { G } & \text { F } & \text { Cement } \\ 608 & 542 & 542 & 463 & 502 & 344\end{array}$

Table 1. Specific surface area of waste glass powders and Portland cement $\left[\mathrm{m}^{2} / \mathrm{kg}\right]$ 1. táblázat A felhasznált hulladéküveg porok és portlandcement fajlagos felülete $\left[\mathrm{m}^{2} / \mathrm{kg}\right]$
The grading curves for the different waste glass powders are given in Fig. 1.

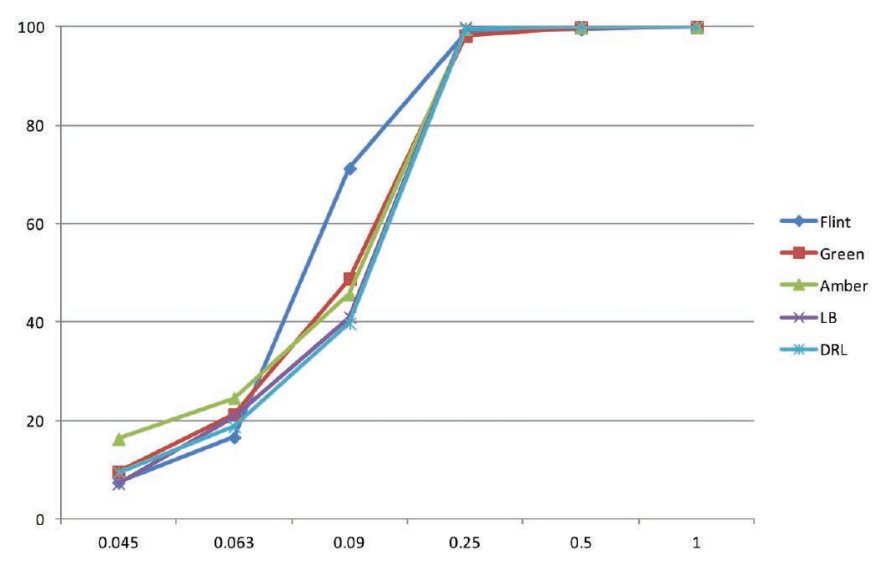

Fig. 1. The grading curves of the WGP materials

1. ábra A hulladéküveg porok szemcseméret eloszlása

\subsection{Preparation of specimens}

Portland cement was substituted with WGP at levels of $20 \%$ or $30 \%$ per mass of cement. The water/binder ratio was selected to be $\mathrm{w} / \mathrm{c}=0.285$. Where cement substitution by WGP was applied, the water/cement ratio was changed to $\mathrm{w} / \mathrm{b}$ $=0.342(20 \% \mathrm{WGP})$ and $\mathrm{w} / \mathrm{b}=0.3705$ (30\% WGP), however, the water/binder ratio was kept constant at $\mathrm{w} / \mathrm{c}=0.285$. The components of the mortar mixture were batched by weight, cement and waste glass were premixed for $2 \mathrm{~min}$, entire amount of water was added and mixed for $3 \mathrm{~min}$, the mortar mixtures were mixed for an additional $5 \mathrm{~min}$, resulting in a total mixing period of $10 \mathrm{~min}$ in a laboratory mortar mixer according to EN 196-1:2005 [15]. The workability of the fresh mortar was tested by flow table test according to EN 1015-3:1999 [16]. For all series, measured flow diameter results are given in [14].

\subsection{Drying shrinkage test}

The test method according to the Hungarian standard MSZ 523-5:1975 [17] was used for the drying shrinkage tests. Three $40 \mathrm{~mm} \times 40 \mathrm{~mm} \times 160 \mathrm{~mm}$ prismatic specimens were prepared for each series to the drying shrinkage tests. The specimens were removed from the moulds after 24 hours and the initial length of the specimens was measured. Specimens were stored in a climatic chamber at $20 \pm 2^{\circ} \mathrm{C}$ temperature and $65 \pm 5 \%$ relative humidity until the deformation measurements at $1,2,3,6,8,9,10,13,14,15,16,17,20,21,23,27,28,30$, $56,91,147,282$ and 592 days of age for specimens with sodalime waste glass powder and at $1,2,3,7,8,9,10,11,14,15$, $17,21,22,29,57,92,148,276$ and 586 days for fluorescent lamp tube and incandescent light bulb borosilicate waste glass powder. The length changes were recorded using comparator Graaf-Kaufmann device according to the method detailed in the Hungarian standard MSZ 523-5:1975[17] (Fig. 2)

\subsection{Early age shrinkage cracking test}

Three ring specimens (see Fig. 3), for each series were prepared for measuring early age shrinkage cracking tendency. After $24 \mathrm{~h}$, the outer steel ring moulds of specimens were 
removed. Then specimens were exposed to drying conditions at $20 \pm 2^{\circ} \mathrm{C}$ temperature and $65 \pm 5 \%$ relative humidity in a climatic chamber. Development of cracks was followed and cracking time was recorded for each ring specimen. Ring specimens were exposed to drying conditions from the outer and both the top and the bottom side of cement paste (see Figs. 4 and 5).

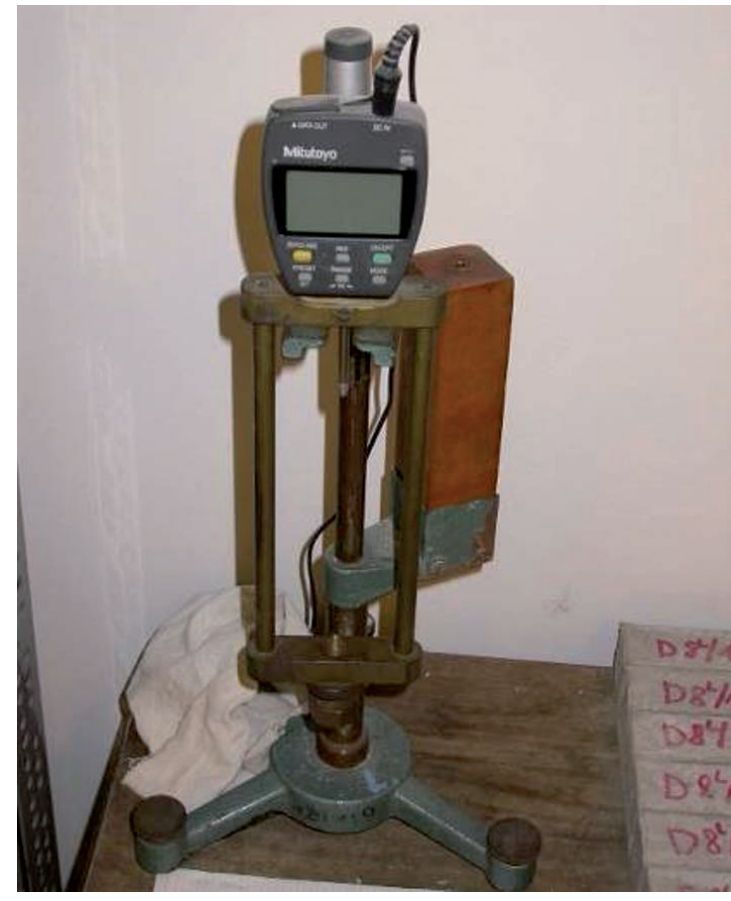

Fig. 2. Graaf-Kaufmann device with Mitutoyo comparator (minimum measuremen interval $0.001 \mathrm{~mm}$ ) with reference specimen

2. ábra Graf-Kaufmann készülék digitális Mitutoyo hosszváltozás-mérővel (felbontás $0,001 \mathrm{~mm}$ ) és referencia etalonnal

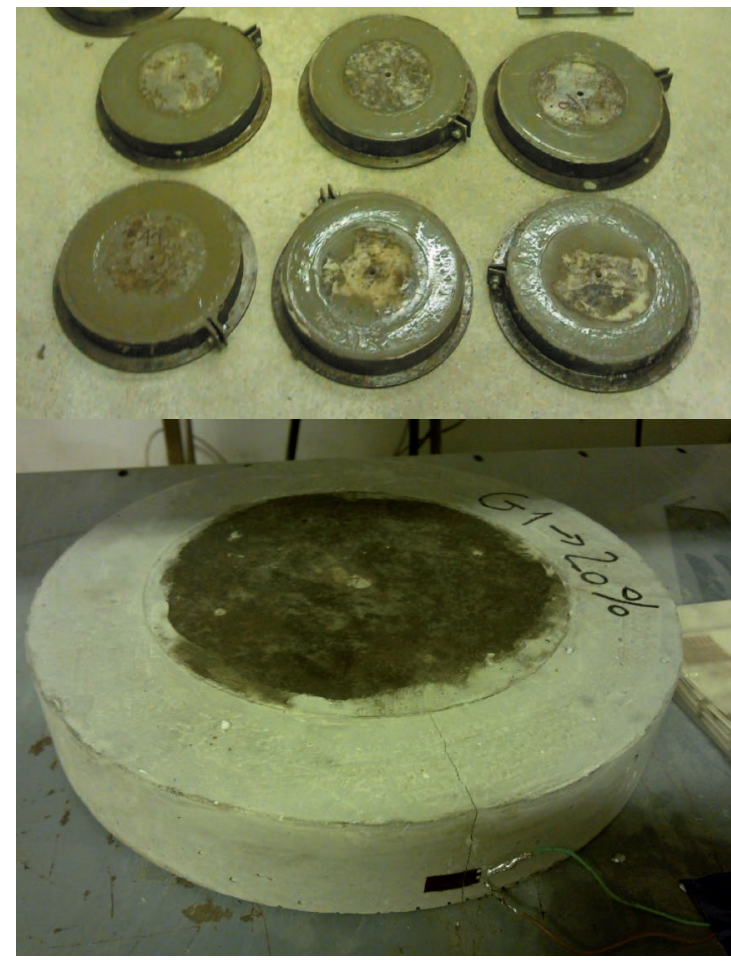

Fig. 3. The preparation and testing of ring specimens for early age cracking tendency 3. ábra A korai zsugorodási repedésérzekenység vizsgálata gyürü alakú próbatesteken

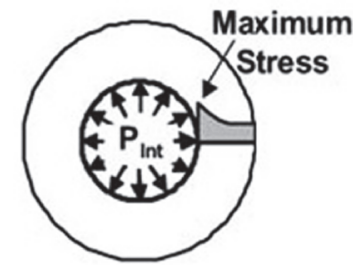

Fig. 4. Typical stress development of a restrained ring specimen [18] 4. ábra Jellegzetes feszültségeloszlás a gyürü alakú próbatestben [18]

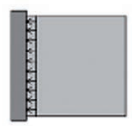

a)

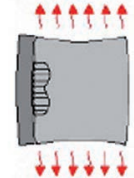

b)

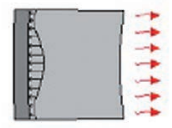

c)
Fig. 5. Influence of drying shrinkage condition on the deformation of cement paste mortar and steel rings: a) uniform shrinkage, b) top and bottom drying, c) circumferential drying [18]

5. ábra A kiszáradás módjának hatása a gyürü alakú próbatest deformációjára: a) egyenletes zsugorodás, b) alsó és felső oldali kiszáradás, c) palástirányú kiszáradás [18]

\section{Results and discussions}

\subsection{Drying shrinkage}

The time development of drying shrinkage values of the hardened cement paste specimens with WGP are indicated in Figs. 6 and 7.

As it can be seen on Figs. 6 and 7 the drying shrinkage of mixtures with $30 \%$ of WGP content are higher than in case of $20 \%$ WGP content. It can be also realized from the results that almost all mixtures provide higher shrinkage than the reference mixture (that was made without WGP). Therefore, it can be concluded that WGP increases drying shrinkage of cement pastes, but it should be noted that the difference is not significant between the reference and the tested mixtures. It is supposed that the tested WGP of high specific surface area can be involved in the hydration of the cement paste. The highest shrinkage was recorded in case of series G2 (green colour) WGP, and the lowest shrinkage was recorded in case of series G3 (amber colour) by testing of both (20\% and $30 \%)$ WGP contents.

As it can be seen in Figs. 6 and 7, the application of soda-lime waste glass powder as cement substitute does not influence negatively the drying shrinkage deformation of cement paste mortars in comparison to the reference specimens, during the period of 592 days (see Table 2). Shrinkage deformation is the highest at early age for the specimens with soda-lime WGP (flint colour) and particularly for green colour at 30\% WGP content. At the same time, green colour WGP (20\%), amber colour WGP (20\% and 30\%) specimens show smaller deformations; nearly equal to that of the reference cement paste specimens. Application of fluorescent lamp tube and incandescent light bulb borosilicate waste glass powder as cement substitute does not influence negatively the drying shrinkage deformation of cement paste mortars in comparison to the reference specimens, during the period of 586 days. The development of the deformations in specimens with WGP addition follows that of the reference cement paste specimens. 


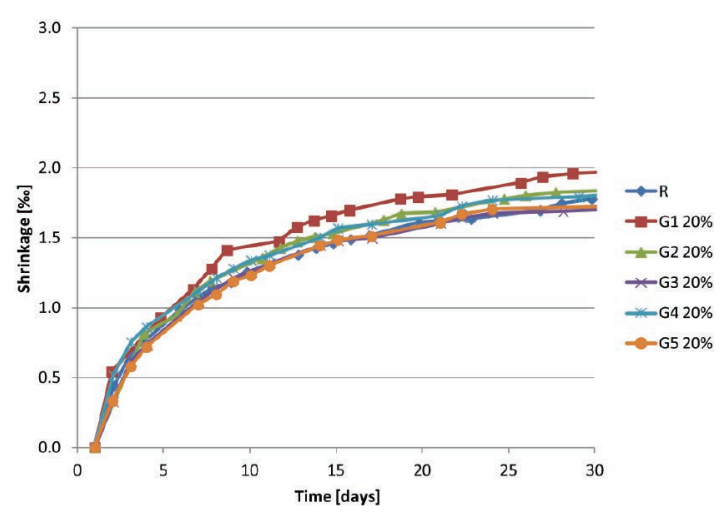

Fig. 6.a. Shrinkage of cement pastes with 20\% WGP content

6.a ábra A 20\% megörölt hulladék üveg tartalmú próbatestek zsugorodása

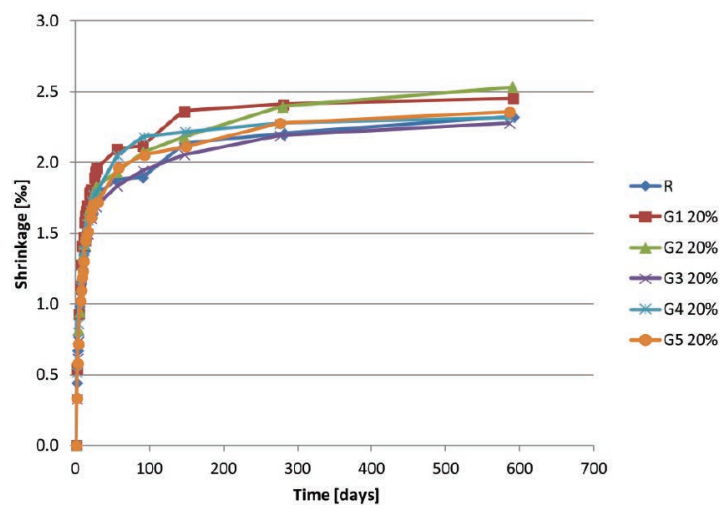

Fig. 6.b. Shrinkage of cement pastes with $20 \%$ WGP content

6.b ábra A 20\% megörölt hulladék üveg tartalmú próbatestek zsugorodása

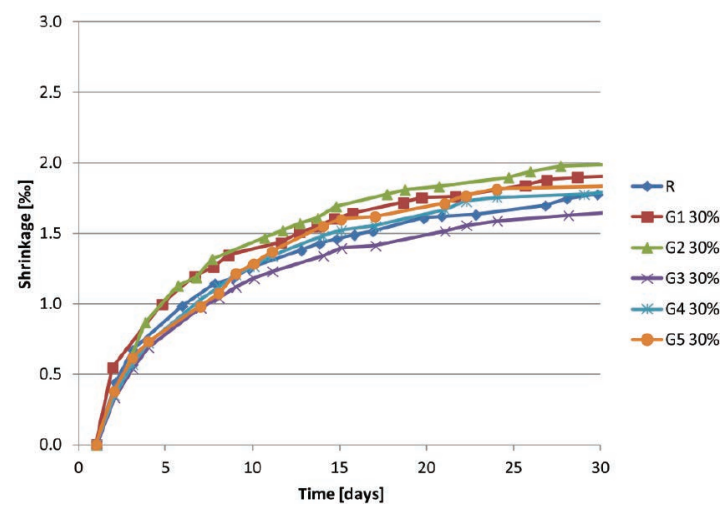

Fig. 7.a. Shrinkage of cement pastes with $30 \%$ WGP content

7.a ábra A 30\% megörölt hulladék üveg tartalmú próbatestek zsugorodása

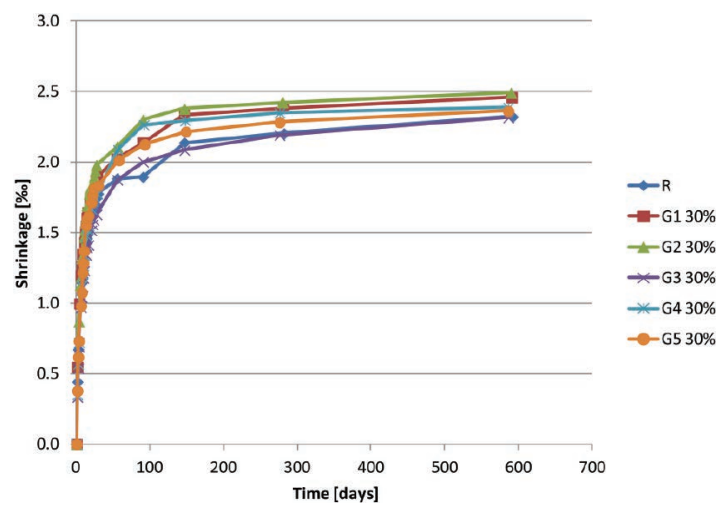

Fig. 7.b. Shrinkage of cement pastes with $30 \%$ WGP content

7.b ábra A 30\% megőrölt hulladék üveg tartalmú próbatestek zsugorodása

\begin{tabular}{|c|c|c|c|c|c|c|}
\hline Name & REF & $\mathbf{F}$ & G & A & LB & DRL \\
\hline $20 \% W G P$ & \multirow{2}{*}{2.32} & 2.45 & 2.53 & 2.28 & 2.32 & 2.36 \\
\hline $30 \%$ WGP & & 2.46 & 2.49 & 2.31 & 2.38 & 2.36 \\
\hline
\end{tabular}

Table 2. Drying shrinkage values of the hardened cement paste specimens at 592 days [\%o] 2. táblázat A zsugorodás végértéke 592 napos korban [\%o]

\begin{tabular}{|c|c|c|c|c|c|c|}
\hline Name & REF & $F(G 1)$ & G (G2) & A (G3) & LB (G4) & $\begin{array}{l}\text { DRL } \\
\text { (G5) }\end{array}$ \\
\hline $20 \%$ GLP & \multirow{2}{*}{32,8} & 40.3 & 43.5 & 43.5 & 49.0 & 44.2 \\
\hline $30 \%$ GLP & & 45.5 & 46.4 & 47.2 & 53.2 & 51.3 \\
\hline Table 3. & $\begin{array}{l}\text { Early age sh } \\
\text { specimens }[\end{array}$ & $\begin{array}{l}\text { kage crack } \\
\text { irs] }\end{array}$ & time va & f the ho & ed cemen & ste \\
\hline 3. táblázat & Az elsö repec & megjelenés & ez tartozó & ótartam \& & üs vizsgál & rán [óra] \\
\hline
\end{tabular}

\subsection{Early age shrinkage cracking}

Table 3 indicates cracking time values for all mixtures tested. The most important result is that the reference mixture had the shortest cracking time, so the early age shrinkage cracking tendencies of mixtures with WGP addition were found to be more favourable than that of the reference mixture. This observation is attributed to the slower setting of the mixtures with WGP addition. The use of LB type (G4) glass powder provided the longest cracking time; this WGP is considered to be the best in the point of view of early age shrinkage cracking tendency. The effectiveness of the other WGPs were - in decreasing order - G5, G3, G2, and finally G1, but the results are very close to each other, so the cracking tendencies can be considered as almost the same. The same observation can be made on effectiveness of the WGPs in case of both $20 \%$ and $30 \%$ substitution levels.

\section{Conclusions}

The present paper has summarised the experimental results of a laboratory test series carried out on cement paste mortar specimens, in which waste glass powder (WGP) addition was used as supplementary cementitious material (SCM) during a cooperation research between the Budapest University of Technology and Economics (BME), Department of Construction Materials and Engineering Geology and the Riga Technical University (RTU), Institute of Materials and Structures (IMS). CEM I $42.5 \mathrm{~N}$ Portland cement was used with WPG substitution at levels of $20 \%$ or $30 \%$ per mass of cement.

It was demonstrated that the WGP addition:

- For $20 \%$ and $30 \%$ per mass of cement seems to be applicable in view of drying shrinkage with total deformation up to $2.5 \%$ in the period of 592 days. The increase in waste glass powder addition leads to an increase in drying shrinkage.

- The highest shrinkage was recorded in case of series G2, green colour soda-lime WGP, and the lowest shrinkage was recorded in case of series G3, amber colour soda-lime WGP by testing of both $(20 \%$ and $30 \%)$ WGP contents. 
- The WGP addition contributes to a slowdown in the rate of hydration of the cement paste, so the early age shrinkage cracking tendency becomes more favourable, which can be seen in the longer cracking time result during the ring tests.

- In the point of view of early age shrinkage cracking tendency, the best performance was realized for series G4, fluorescent lamp tube WGP, at both $20 \%$ and $30 \%$ substitution levels. The other WGPs provided almost the same early age shrinkage cracking tendency, needed about $35 \%$ more time for the appearance of the first early age crack, compared to the reference cement paste.

\section{Acknowledgement}

Authors gratefully acknowledge the support of the Hungarian Scientific Research Fund project "Durability and performance characteristics of concretes with novel type supplementary materials" (OTKA K 109233).

\section{References}

[1] European Commission (2012) Preparing a Waste Prevention Programme - Guidance document. Drafted by BioIntelligence Service S.A.S., Paris, October 2012, 62 p. http://ec.europa.eu/environment/waste/prevention/ pdf/Waste\%20prevention\%20guidelines.pdf

[2] EEA (2008) Energy and Environment report. EEA Report No. 6/2008. European Environment Agency, Copenhagen, 100 p. http://dx.doi.org/10.2800/10548

[3] EEA (2013) Managing municipal solid waste - a review of achievements in 32 European countries. EEA Report No. 2/2013. Appendix ETC/SCP Working paper prepared by Herczeg, M.: Municipal waste management in Hungary. European Environment Agency, Copenhagen, 19 p. http://www.eea.europa.eu/publications/managing-municipal-solid-waste

[4] Balatoni, H. (2012) Situation of the Hungarian waste management industry. Conference presentation held at: Új utakon a hazai hulladékgazdálkodás, International Waste Management Conference, organized by the National Waste Management Agency - NWMA, Országos Hulladékgazdálkodási Ügynökség - OHÜ, 13-15 June 2012, Gödöllő, Hungary

[5] European Commission (2011) Country Factsheet for Latvia (LV). In: Support to Member States in improving waste management based on assessment of Member States' performance, 070307/2011/606502/ SER/C2, Final Report, 7 May 2013, BiPRO, Beratungsgesellschaft für integrierte Problemlösungen, 17 p. http://ec.europa.eu/environment/ waste/framework/pdf/LV\%20factsheet_FINAL.pdf

[6] Hoffmann, L., Józsa, Zs., Nemes, R. (2003) Üveghulladékból könnyűbeton adalékanyag. Épitöanyag Vol. 55, No. 1, pp.13-17.

[7] Shao, Y., Lehoux, P. (2001) Feasibility of Using Ground Waste Glass as a Cementitious Material. Proceedings of the International Symposium: Recycling and reuse of Glass Cullet, Dundee, Scotland, pp. 209-219.

[8] Shao, Y., Lefort, T., Moras, S., Rodriguez, D. (2000) Studies on concrete containing ground waste glass. Cement and Concrete Research, Vol. 30, No. 1, pp. 91-100. http://dx.doi.org/10.1016/S0008-8846(99)00213-6

[9] Dyer, T. D., Dhir, R. K. (2001) Chemical reactions of glass cullet used as cement component. ASCE Journal of Materials in Civil Engineering, Vol. 13, No. 6, pp. 412-417. http://dx.doi.org/10.1061/(ASCE)0899-1561(2001)13:6(412)

[10] Shayan, A., Xu, A. (2004) Value-added utilization of waste glass in concrete. Cement and Concrete Research, Vol. 34, No. 1, pp. 81-89. http://dx.doi.org/10.1016/S0008-8846(03)00251-5

[11] Shayan, A., Xu, A. (2006) Performance of glass powder as a pozzolanic material in concrete: a field trial on concrete slabs. Cement and Concrete Research, Vol. 36, No. 3, pp. 457-468.

http://dx.doi.org/10.1016/j.cemconres.2005.12.012
[12] Pereira-de-Oliveira, L. A., Castro-Gomes, J. P., Santos, P. M. S. (2012) The potential pozzolanic activity of glass and red-clay ceramic waste as cement mortars components. Construction and Building Materials, Vol. 31, pp. 197-203. http://dx.doi.org/10.1016/j.conbuildmat.2011.12.110

[13] Byars, E. A., Morales-Hernandez, B., Zhu, H. Y. (2004) Waste glass as concrete aggregate and pozzolan. Concrete, Vol. 38, No. 1, pp.41-44.

[14] Borosnyói, A., Kara, P., Mlinárik, L., Kase, K. (2013) Performance of Waste Glass Powder (WGP) Supplementary Cementitious Material (SCM) Workability and Compressive Strength. Épitöanyag-Journal of Silicate Based and Composite Materials, Vol.65, No. 3, pp.90-94. http://dx.doi.org/10.14382/epitoanyag-jsbcm.2013.17

[15] CEN (2005) EN 196-1:2005, Methods of testing cement - Part 1: Determination of strength. European Standard. CEN/TC 51 - Cement and building limes, 2005-08-31

[16] CEN (1999) EN 1015-3:1999, Methods of test for mortar for masonry - Part 3: Determination of consistence of fresh mortar (by flow table). European Standard. CEN/TC 51 - Cement and building limes, 1999-08-31

[17] MSZT (1975) MSZ 523-5:1975, A cementek fizikai jellemzőinek vizsgálata. A térfogatállandóság meghatározása. Testing physical parameters of cements. Determination of volume stability. Hungarian Standard

[18] Banthia N., Gupta R. (2007) Test method for evaluation of plastic shrinkage cracking in fiber-reinforced cementitious materials. Experimental Techniques, Vol. 31, No. 6, pp. 44-48.

http://dx.doi.org/10.1111/j.1747-1567.2007.00191.x

$\underline{\text { Ref.: }}$

Kara, P. - Borosnyói, A. - Fenyvesi, O.: Performance of waste glass powder (WGP) supplementary cementitious material (SCM) Drying shrinkage and early age shrinkage cracking Építöanyag - Journal of Silicate Based and Composite Materials, Vol. 66, No. 1 (2014), 18-22. p. http://dx.doi.org/10.14382/epitoanyag-jsbcm.2014.4

Megőrölt hulladék üveg (WGP) cement kiegészítő anyag (SCM) tulajdonságai - Száradási zsugorodás és korai zsugorodási repedésérzékenység

Az Európai Unió direktívái a csomagolóanyagok újrahasznosítására vonatkozóan is megfogalmaznak irányelveket, amelyek a tagállamok számára iránymutatásként szolgálnak. Jelen kutatás során lett-magyar közös kutatási projektben, a Rigai Múszaki Egyetem (RTU) és a Budapesti Múszaki és Gazdaságtudományi Egyetem (BME) kutatói tanulmányozták a hulladék üveg újrahasznosításának lehetôségét. Több eltérô, hulladéküveg alapanyagból készült, laboratóriumi körülmények között finomra ôrölt üvegpor, cement kiegészítô anyagként történố felhasználási lehetôségét vizsgálták. A megốrölt hulladék üvegpor adagolásának mennyisége $20 \%$ és 30\% volt a cement tömegére vonatkoztatva. A cikkben a száradási zsugorodás mértéke és a korai zsugorodási repedésérzékenység bemutatása történt meg, megszilárdult cementkô próbatestek laboratóriumi vizsgálatát követôen. Sikerült igazolni, hogy a száradási zsugorodás szempontjából a megórölt hulladék üvegpor alkalmazása nem kedvezôtlen, a vizsgált adagolások esetén. A zsugorodás mértéke 2,5 \%o, 592 napos korban. A korai zsugorodásból származó repedésérzékenységet a megôrölt hulladék üvegpor adagolása kedvezôen befolyásolja; a gátolt zsugorodásból származó elsố repedés kialakulása késôbbi időpontban következik be, mint a cement kiegészítố anyagot nem tartalmazó referencia keverék esetén.

Kulcsszavak: újrahasznosítás, hulladék üveg, cement kiegészítô anyag, száradási zsugorodás, korai zsugorodási repedésérzékenység 